\title{
INTERNALISASI PERSPEKTIF BHINEKA TUNGGAL IKA DALAM PENDIDIKAN AGAMA ISLAM DI INDONESIA
}

\author{
Rozib Sulistiyo \\ Kepala MI al-Islam Tonoboyo, Magelang \\ Mahasiswa Program Magister Pendidikan Islam \\ Pasca Sarjana UIN Sunan Kalijaga Yogyakarta \\ mitonoboyo@gmail.com
}

\begin{abstract}
abstrak: Penelitian ini bertujuan untuk menggali perspektif Bhinneka Tunggal Ika (BTI) yang identik dengan gagasan multikulturalisme dalam ajaran Islam secara literer. Dari penelusuran secara filosofis dapat dikembangkan untuk penguatan implementasi pendidikan agama Islam di Indonesia. Melalui filsafat Islam bisa diketahui bahwa manusia dalam penerimaan tatanan moralnya tidak selalu sama dengan manusia lainnya. Ketidaksamaan ini disebabkan karena perbedaan karakter alamiah yang mendasari setiap individu. Implikasinya dalam menerima perbaikan juga sangat beragam. Perspektif BTI itu bisa dikembangkan dalam Pendidikan Agama Islam. Untuk itu, pendidik diharuskan untuk menentukan strategi yang tepat guna membentuk pribadi muslim Indonesia bersusila menghargai kemajemukan.
\end{abstract}

Kata kunci: internalisasi, Bhineka Tunggal Ika, Pendidikan Agama Islam

abstract: This study aims to explore the perspective of Unity in Diversity or Bhinneka Tunggal Ika (BTI) which is identical to the idea of multiculturalism in Islamic teachings in a literal manner. From a philosophical search can be developed to strengthen the implementation of Islamic religious education in Indonesia. Through Islamic philosophy it can be seen that humans in accepting their moral order are not always the same as other humans. This inequality is caused by differences in the natural character underlying each individual. The implications for receiving repairs are also very diverse. The BTI perspective can be developed in Islamic Education. For this reason, educators are required to determine the right strategies to shape Indonesian Muslim individuals who despise pluralism.

Keywords: internalization, Bhineka Tunggal Ika, Islamic Religious Education

\section{A. Pendahuluan}

Garcia mengungkapkan,"pluralistic theaching and learning as synonymous with multikultural education”. ${ }^{1}$ Penyamaan definisi antara

${ }^{1}$ Ricardo L. Garcia, Theaching In Pluralistic Society (Harper \& Row Publishers, New York, 1982), h. 8 
pendidikan plural dan pendidikan multicultural juga bisa dapat dilihat pada uraian Thoha Hamim. Ia menyatakan bahwa perbedaan pengistilahan tersebut pada hakekatnya mendukung makna yang sama. Perbedaan yang terjadi hanya karena perbedaan negara yang mengetrapkan prinsip tadi. Sebagai contoh di Amerika serikat biasa menggunakan sebutan Melting Pot Society. Kanada menamai Multiculturalism Community, India menyebutnya dengan Composite Society. Di Indonesia ide tersebut bahkan telah dikenal sebagai Bhinneka Tunggal Ika².

Walaupun demikian, beberapa pakar dan tokoh pendidikan di Indonesia ada yang masih bersikukuh untuk membedakannya. Lainnya menyatakan multikulturalisme adalah perangkat analisa atau perspektif guna memahami dinamika keanekaragaman latar belakang budaya, perbedaan sejarah, suku bangsa, rasial, golongan dan agama. Sedangkan pluralitas adalah kemajemukan dalam arti luas.

Meski demikian bisa ditemukan kesamaan terhadap relasi pendidikan dengan kebudayaan di dalam Bhineka Tunggal Ika (BTI). Hamid menyatakan bahwa multikultural adalah keragaman dalam hal budaya3. Lebih lengkap pula, Mc Lean mengkategorikan masyarakat multikultural sebagai perihal adanya perbedaan (The Existence of Diversity) sekurang-kurangnya perbedaan dalam akses ekonomi dan pendidikan, hak warga negara dan hak politik serta perbedaan dalam masing-masing nilai budayanya yang kesemuanya membangun komitmen untuk hidup bersama dalam satu negara kesatuan4.

Perbedaan filosofis ini ternyata tidak menggambarkan perbedaan pemikiran barat dan timur seperti yang utarakan oleh Hilman tentang filsafat pendidikan.5 Mengingat arti penting perspektif BTI yang identik

${ }^{2}$ Ismail SM \& Abdul Mukti, Pendidikan Islam, Demokratisasi dan Masyarakat Madani (Yogyakarta: Pustaka Pelajar, 2000), h. 127

3 S. Hamid Hasan, "Pendekatan Multikultural Untuk Penyempurnaan Kurikulum Nasional," http://www.depdiknas.go.id/Jurnal/26/hamid

4 Fattah Hanurawan, "Multikultural Perpective In Indonesian Sosial Sciences Studies And Student Prejudice Reduction” Jurnal Ilmu Pendidikan 5 No. Suplemen (1998), h. 14-35.

5 Hilman Haroen, "Epistimologi Idealistik Syekh Az-Zarnuji, Telaah Naskah Ta'lim Muta'allim,” Jurnal Studi Islam Profetika 15, no. 2 (2016), 16o-174. 
dengan gagasan multikulturalisme bagi kehidupan keberagamaan di Indonesia, penelitian ini bermaksud menelusurinya dalam ajaran Islam. Dari penelusuran tersebut dapat dikembangkan untuk penguatan implementasi pendidikan agama islam (PAI). Oleh karena itu, kajian filosofis kemudian dikaitkan dengan kebutuhan pendidikan berciri khas keislaman di Indonesia dapat memberikan kontribusi bagi kesatuan bangsa dan Negara Indonesia dengan melestarikan keragaman budaya adi luhung melalui wajah nasionalnya, Bhineka Tunggal Ika (BTI)

\section{B. Bhineka Tunggal Ika dalam Ajaran Islam}

Hasan menunjukkan ide BTI, sebagai varian dari kemajemukan yang juga berarti kemajemukan dalam hal budaya ${ }^{6}$ adalah sebuah fakta kehidupan atau "hukum sejarah" (sunnatullah) yang tak mungkin terelakkan. Karena memang merupakan sesuatu yang given (kodrati) dalam kehidupan, sebagaimana faktanya termaktub dalam Al-Quran surat Al-Hujurat (49) ayat 13:

"Hai manusia, sesungguhnya Kami menciptakan kalian dari seorang laki-laki dan seorang perempuan dan menjadikan kamu berbangsa-bangsa dan bersuku-suku supaya kamu saling kenal-mengenal..."

Juga pada surat Ar-Ruum (30),

"Dan di antara tanda-tanda kekuasaan-Nya ialah menciptakan langit dan bumi dan berain-lainan bahasamu dan warna kulitmu"

Allah juga menciptakan kemajemukan ummat, meski Ia mampu menciptakan satu ummat manusia saja, agar tiap-tiap mereka berlomba menuju kebaikan. Bahkan hal itulah yang menjadi tujuan-Nya mencipta manusia, sebagaimana termaktub dalam surat Hud (11) ayat 118-119:

Jikalau Tuhanmu menghendaki, tentu Dia menjadikan manusia ummat yang satu, tetapi mereka senantiasa berselisih pendapat, kecuali orang-orang yang diberi rahmat oleh Tuhanmu. Dan untuk itulah Allah menciptakan mereka.

pada surat Al-Maidah (5) ayat 48, Nasional,"

6 Hasan, "Pendekatan Multikultural Untuk Penyempurnaan Kurikulum 
Sekiranya Allah menghendaki, niscaya kalian dijadikan-Nya satu ummat saja, tetapi Allah hendak menguji kalian terhadap pemberian-Nya kepada kalian, maka berlombalombalah berbuat kebajikan.

Boisard kemudian merumuskan, dari segi metafisik manusia pada dasarnya sama karena mereka adalah mahluk Tuhan, maka Islam memandang bahwa prinsip persamaan adalah soko guru yang mendasari konstruksi sistem sosial.7 Pernyataan diatas diperkuat dengan mengutip sebuah ayat al-Qur'an yang berbunyi: ${ }^{8}$

Sesungguhnya Fir'aun telah berbuat sewenang-wenang di muka bumi dan menjadikan penduduknya berpecah belah, dengan menindas segolongan dari mereka, menyembelih anak laki-laki mereka dan membiarkan hidup anak-anak perempuan mereka. Sesungguhnya Fir'aun termasuk orang-orang yang berbuat kerusakan.

Islam membuat penggolongan manusia atas dasar hubungannya dengan Tuhan, bukan atas dasar darah, warna kulit, daerah, keturunan, kedudukan atau tingkat kekayaan. Pembagian yang hanya didasarkan atas pangkat atau derajat semacam itu hanya akan membawa sikap congkak dan takabur, bukan menjalin hubungan sesama dengan saling berlomba dalam kebaikan dengan menghormati perbedaan strata sosial masingmasing. 9

Konstruksi sistem sosial Islam kemudian ditegakkan atas beberapa prinsip sebagai berikut: ${ }^{10}$

1) Persamaan, karena sekakek dan senenek

2) Persaudaraan karena umat yang satu

3) Persatuan, karena disuruh olehg Allah untuk bersatu dan dilarang untuk berpecah belah ${ }^{11}$, perpecahan menimbulkan kelemahan ${ }^{12}$ karena

7 Marcel A. Boisard, Humanisme Dalam Islam, cet. I (Jakarta: Bulan Bintang, 1980), terj. Rasyidi, h. 112.

8 Q.S. al Qasas (28): 4

9Imam Munawir, Memahami Prinsip-Prinsip Dasar Al-Islam (Surabaya: PT. Bina Ilmu, t.t.), h.74

10 Tim Dosen IAIN Sunan Ampel Malang, Dasar-Dasar Kependidikan Islam; Suatu Pengantar Ilmu Pendidikan Islam (Surabaya, Karya Abdi Tama: 1996), h. 107-108 ${ }^{11}$ Q.S. ali Imran : 103

12 Q.S. al Anfal : 46 
itu kalau terjadi perbedaan pendapat hendaklah kembali kepada Allah dan Rosulnya

4) Kasih sayang yang merupakan ciri orang yang beriman

5) Tolong menolong karena diperintahkan oleh Allah

6) Keseimbangan antara individu dengan individu yang lain, antara individu dengan masyarakat, antara masyarakat dengan masyarakat yang lain, serta hak dan kewajiban karena segala sesuatu yang diciptakan Allah dalam keadaan berpasangan ${ }^{13}$, dan bagi pasangan tersebut berlaku hukum keseimbangan ${ }^{14}$ kalau tidak terdapat keseimbangan maka akan rusak.

7) Musyawarah, karena diperintahkan oleh Allah. Apapun persoalan yang dihadapi dan atau digarap maka harus dimusyawarahkan dengan seluruh anggota masyarakat.

8) Anggota masyarakat harus memiliki akhlak yang terpuji dan bersih dari akhlak tercela.

9) Menjauhi segala yang haram karena diperintahkan oleh Allah SWT

Secara historis diketahui bahwa terhadap kemajemukan, Rasulullah saw, para sahabat dan pengikutnya telah menunjukkan pada dunia tentang bagaimana cara hidup dan bergaul. Saat menjadi pemimpin di Madinah, kondisi masyarakatnya tidak homogeny. Mereka terdiri dan beragam bangsa (Arab dan Bani Israel), suku (Aus, Khajraj, Quraisy dan lainnya), kelompok (Muhajirin dan Anshar) dan agama (Islam, Yahudi dan paganis). Untuk menggalang persatuan, Rasulullah kemudian mengadakan perjanjian persatuan dan kerjasama seperti yang tertuang dalam Piagam Madinah tepatnya pada pasal 25 yang berbunyi:

Kaum Yahudi dari Suku Bani Auf adalah satu bangsa negara dengan warga yang beriman. Kaum Yahudi bebas memeluk agama mereka sebagaimana muslim bebas memeluk agama mereka. Kebebasan ini berlaku juga terhadap pengikutpengikut sekutu-sekutu mereka dan diri mereka sendiri

14 Q.S. al Syuro: 17; Q.S. al Rahman : 7-8 
kecuali kalau ada yang mengacau dan berbuat kejahatan yang menimpa diri orang yang bersangkutan dan keluarganya. ${ }^{15}$

Pasal tersebut menandaskan adanya sikap inklusivitas dalam kemajemukan beragama. Lebih jauh, fenomena kebhinekaan dalam hal agama disikapi oleh masyarakat secara umum dengan beberapa kategori: Pertama, Ekskluvisme Absolut. Artinya, semua agama yang lain itu salah, hanya agamanya sendiri yang benar. Kedua, Relativisme Absolut. Artinya, semua agama itu relatif. Ketiga, Inklusivisme. Artinya, agama kita benar, agama orang lain juga benar. Dan keempat, Inklusivisme Hegemonik. Artinya, agama kita benar, agama orang lain itu salah. Tetapi, mereka bisa hidup secara berdampingan dengan kita ${ }^{16}$.

Secara sosiologis, kondisi sosial budaya dengan pola kemajemukan selalu memerlukan adanya titik temu dalam nilai kesamaan (Kalìmatun $S a w \bar{a})$ persetujuan perdamaian ${ }^{17}$ dari semua kelompok yang ada. Melalui Islam, dituntutlah umat manusia menuju persaudaraan (ukhuwah) universal tanpa membedakan keturunan, suku, ras maupun golongan. Ukhuwah bisa hidup subur, karena al-Qur'an mengajarkan prinsip musyawarah guna menyelesaikan masalah musawah (persamaan) guna menghilangkan gap antara masing-masing kelompok karena perbedaan status sosial, takaful al-ïtima (tanggung jawab bersama) guna menanamkan solidaritas, ta'awun (saling tolong menolong) guna menanamkan kerja sama yang melahirkan kekuatan, tasamuh (toleran) guna menumbuhkan sikap saling hormat menghormati yang dilandasi oleh setuju perbedaan pendapat. ${ }^{18}$

Dalam ayat-Nya, Allah berfirman:

Hai manusia, sesungguhnya Kami menciptakan kamu dari seorang laki-laki dan seorang perempuan dan menjadikan kamu berbangsa-bangsa dan bersuku-suku supaya kamu saling kenal-mengenal. Sesungguhnya orang yang paling

15 Zainal Abidin Ahmad, Piagam Nabi Muhammad Saw Konstitusi Negara Tertulis Yang Pertama Di Dunia (Jakarta:Bulan Bintang, 1973), h. 26

${ }^{16}$ Amiruddin, Pluralisme: Wacana, Praktek Dan Penolakan, http// www.lkis.org. / riset

17 Boisard, Humanisme Dalam Islam, h. 141.

${ }_{18}$ Imam Munawir, Salah Paham Terhadap Al-Quran, (Surabaya: PT Bina Ilmu, 1983), h.157 
mulia diantara kamu disisi Allah ialah orang yang paling takwa diantara kamu. Sesungguhnya Allah Maha Mengetahui lagi Maha Mengenal. ${ }^{19}$

Maududi menunjukkan kandungan arti persaudaraan antara seluruh manusia (pesaudaraaan Internasional). Dijadikannya manusia ke dalam berbagai ras, suku, golongan dan bangsa adalah demi pergaulan, sehingga akan tercipta jalinan persaudaraan yang harmonis. Ia melanjutkan, intinya adalah bahwa Islam tidak mengenal adanya superioritas bangsa terhadap bangsa lain. Dijadikannya manusia bersuku-suku dan berbangsa-bangsa tidak bertujuan agar suatu bangsa membanggakan keunggulan terhadap bangsa lain. Tidak pula dimaksudkan agar suatu bangsa menghina, mencemarkan dan menganggap bangsa lain sebagai bangsa dan suku yang rendah, serta merampas hak mereka dengan sewenang-wenang. Sebab, segala keunggulan, kesalehan dan baik tidaknya seseorang dari yang lainnya tergantung pada ketaqwaannya. ${ }^{20}$

Masyarakat Islam adalah masyarakat yang universal, tidak rasial, tidak nasional dan tidak pula terbatas di dalam lingkaran-lingkaran geografis. Dia terbuka untuk seluruh anak manusia tanpa memandang jenis, warna kulit atau bahasa bahkan tidak memandang agama dan keyakinan. ${ }^{21}$ Sejak semula Islam meniadakan dinding rasial dan jenis manusia, lalu mengembalikan kepada asal yang satu dan menetapkan tidak ada kelebihan-kelebihan suatu jenis dari jenis yang lainnya dan tidak ada keistimewaan suatu ras di atas ras-ras yang lain. Perbedaan warna kulit dan bahasa tidaklah mengandung arti keistimewaan atau kelebihan, yang dikehendaki hanyalah saling berhubungan dengan baik dan bukan saling mencari perbedaan. Pengakuan tersebut menghasilkan tidak dijumpainya kemelut rasisme (ethnic hatred) dalam dunia Islam²2.

Pembuktian telah dilakukan oleh Lewis saat meneliti elemen-elemen rasisme dalam masyarakat Muslim. Ia tidak menemukan indikasi ke arah praktek-praktek tersebut. Kesulitan yang dialami oleh Lewis dalam

${ }^{19}$ Q.S. al-Hujurat (49): 13 .

20 Abu a'la al-Maududi, Hak-Hak Manusia Dalam Islam, cet. 1 (Jakarta: t.t.), terj. Ummi Haranain h. 25-26.

${ }^{21}$ Munawir, Salah Paham Terhadap Al-Quran, h. 157.

22 Mukti, Pendidikan Islam, h. 123 
menemukan indikasi tersebut karena masyarakat muslim sudah menjadikan asas kesetaraan sebagai paradigma kehidupan sosial mereka ${ }^{23}$. Hal tersebut telah membuktikan bahwa Islam telah membuka semua pintunya untuk semua manusia atas dasar persamaan yang sempurna dan dilandasi perikemanusiaan yang murni.

Qutb menyuarakan hal yang senada. Tidak ada yang paling dibenci oleh rasa keislaman, selain demi arogansi yang dibakar oleh rasa keunggulan ras sendiri ala Nazi dan Yahudi. kesombongan warna kulit seperti yang dipraktekan oleh orang Amerika terhadap orang Indian dan Negro, atau seperti Afrika Selatan dengan politik apartheid-nya terhadap seluruh kulit berwarna pun tiak ditemukan. ${ }^{24}$

Karena Islam, rasialisme yang telah membudaya selama berabadabad secara perlahan dapat dihapuskan. Islam berhasil menyatukan bangsa Arab sehingga terciptanya kasih sayang, kemesraan dan meningkatkan tali persaudaraan diantara sesama pemeluknya. ${ }^{25}$

Dalam surat Ali Imrân ayat 103, Allah swt menegaskan,

Dan berpegangteguhlah kalian kepada tali (agama) Allâh, dan janganlah bercerai berai, dan ingatlah akan nikmat Allâh yang diberikan kepadamu ketika kamu dahulu (masa jahiliyah) bermusuh-musuhan, maka Allâh mempersatukan hatimu, lalu menjadikan kamu melalui nikmat Allâh itu menjadi orangorang yang bersaudara. Dan tatkala kalian telah berada di jurang neraka, lalu Allâh menyelamatkan kamu dari padanya. Demikian Allâh menerangkan ayat-ayat-Nya kepadamu agar kamu mendapat petunjuk.

Ayat tersebut menyatakan adanya fenomena kebhinekaan, yaitu tidak ada perintah untuk bersatu dalam wadah yang tunggal dan monolotik, melainkan bersatu dalam keanekaragaman. Dalam artian, dibalik berbagai macam perbedaan terdapat potensi kerukunan berdasarkan akar-akar persamaan dan kebersamaan. Perbedaan bukan lagi dilihat sebagai pengelompokkan ego semacam etnis, suku, budaya dan agama, tapi lebih sebagai sebuah sistem yang terdiri dari bagian-bagian

23 Ibid

24 Sayyid Quthub, Masyarakat Islam (Bandung: Ma'arif, 1975), h. 70

25 Abdurrazaq Naufal, Al-Qur'an dan Masyarakat Modern, (Jakarta: Mutiara, 1978), h. 29. 
yang bekerja sama untuk mencapai tujuan bersama. Nilai-nilai kemanusiaan universal hendaknya diletakkan dalam tataran kepentingan yang lebih kosmopolit (meliputi seluruh komponen bangsa), dan egaliter (kesamaan derajat kemanusiaan ), baik dalam tataran sosial, ekonomi maupun politik. Oleh karena itu, al-Qur'an mengatakan, “...janganlah bercerai berai...” Mengisyaratkan adanya perbedaan namun tetaplah utuh agar mudah mengorganisasikan diri, dan saling belajar sehingga kehidupan menjadi dinamis ${ }^{26}$.

Dari Quran dan sunnah bisa dibedakan tiga bentuk ukhuwah, persaudaraan sesama islam (Ukhwwwah Islamiyah), persaudaraan sebangsa (Ukhuwwah Wathaniyyah) dan persaudaraan sesama manusia (Ukhuwwah Basyariyah). ${ }^{27}$ Persaudaraan Islam, bukanlah persudaraan yang bersifat ekslusif, persaudaraan yang terbatas pada umat Islam saja. ${ }^{28}$ akan tetapi bersifat universal sesuai dengan yang diajarkan Quran. Karena itu, Mengakui dan menghargai perbedaan dan keragaman sesungguhnya menjadi doktrin fundamental Islam.

Secara normatif, Islam adalah agama yang kitab sucinya dengan tegas mengakui hak-hak agama lain ${ }^{29}$, bahkan terhadap seorang ateis pun, umat harus menunjukkan sikap persudaraannya. Sudah tentu selama tidak mengganggu sendi-sendi kehidupan,30 serta tidak berniat untuk memusuhi umat islam. ${ }^{31}$ Keyakinan bahwa Quran memberikan akomodasi bagi pertumbuhan dan perkembangan faham dalam masyarakat inilah yang menjadi dasar toleransi sejati dalam sejarah Islam yang harus diupayakan demi kepentingan manusia sendiri sebagai usaha menciptakan kedamaian hidup serta toleran dan rukun sebagai bukti adanya iman.

${ }_{26}$ Waidl, Pendidikan Yang Menghargai Kemajemukan, Bulletin Jum'at alIkhtilaf, No. 07/9 Juni 2000 Ikhtilaf dalam http//www.lkis.org./Bulletin ${ }_{27}$ Andree Feillard, NU Vis-a -Vis Negara; Pencarian Isi Bentuk Dan Makna. (Yogyakarta: LKIS, 1999), h.376

${ }^{28}$ Ahmad Syafii Maarif, Peta Bumi Intelektualisme Islam di Indonesia (Bandung: Mizan, 1993), h.238

29M. Deden Ridwan, Membangun Teologi Kerukunan, http:// www.topcities.com/cgi-bin/affiliates/clickcount.cgi?url=www.thefreesite.com

30 Koentjaraningrat, Bunga Rampai Kebudayaan, Mentalitas Dan Pembangunan (Jakarta: Gramedia, 1994), h. 71

${ }_{31}^{1}$ Maarif, Peta Bumi Intelektualisme Islam di Indonesia, h. 238 
Toleransi sebagai kunci kedamaian hidup dapat tercapai jika ikatan kesatuan sudah terwujud dalam bentuk kesadaran pada masing-masing individu dalam masyarakat, sehingga kebahagiaan atau penderitaan orang secara moral diartikan sebagai kebahagiaan atau penderitaan orang lainnya. Karenanya Allah menyuruh kepada manusia berusaha membuat perdamaian di antara sesamanya. ${ }^{32}$ Heikal kemudian menandaskan;

Apabila kebebasan aqidah sudah membuat manusia saling menghormati, membuat mereka mencari kesempurnaan dengan cara toleransi, persaudaraan dan saling mencintai, semuanya merupakan faktor penting yang mendorong ke arah kemajuan dan membuat dunia menjadi aman dan damai. Karena timbulnya peperangan dan huru-hara besar adalah akibat ulah manusia sendiri yang sangat membesarbesarkan sebab-sebab perbedaan di antara mereka. akibatnya, jurang perbedaan di antara mereka menjadi kian lebar bahkan kemudian menjadi penyebab timbulnya rasa benci dan permusuhan yang berakhir dengan pertikaian dan peperangan. 33

Dengan demikian, nilai manusia sesungguhnya lebih ditentukan oleh loyalitasnya dalam menjalin interaksi horizontal (sosial) dalam kerangka pemikiran transendental yang bertumpu pada kedalaman iman dan taqwa. Berpijak dari kenyataan bahwa manusia memiliki kemampuan ganda di atas, yaitu kegagalan dan keberhasilan moral, berdasarkan pada konflik yang telah diberikan pada fitrah manusia, maka mutlak diperlukan adanya suatu bentuk sosialisasi dan internalisasi budaya yang akan membimbing manusia ke arah tujuan luhur, baik dalam kerangka interaksi vertikal maupun horizontal (sosial). Sebagai sebuah sarana sosialisasi dan internalisasi nilai-niai inilah pendidikan memperoleh tempatnya.

\section{Bhineka Tunggal Ika Dalam Pendidikan Agama Islam}

Islam sangat memperhatikan konteks kebhinekaan sosial-budaya sebagai sebuah input bagi pendidikan. Hal tersebut dapat dibuktikan melalui sejarah proses pembudayaan ajaran Islam secara lintas geografis maupun waktu baik pada zaman permulaan Islam, keemasan Islam

${ }^{32}$ Q.S. al-Hujurat (49) : 10

33 Moh. Husain Heikal, Pemerintahan Islam, cet. I. (Jakarta: Pustaka Firdaus, 1990), terj. M. Adib Bisri,. 
(Cordova) maupun zaman neomodernisme saat ini34. Sikap relativitas budaya dalam pendidikan merupakan dasar dari para pendidik muslim dalam pendidikan. Proses pendidikan yang menekankan pada sisi Human Right sangat ditonjolkan dalam Islam, karena sikap tersebut merupakan dasar dan fundamen utama terbentuknya etika kehidupan bagi anak didik untuk siap hidup dalam masyarakat, terutama masyarakat multikultural seperti Indonesia pada zaman global ini35.

Dalam pendidikan Islam, hak asasi manusia (HAM) adalah penjabaran aktual dari akhlak. Oleh karena itu, sikap tersebut harus terlebih dahulu tercermin dalam materi pendidikan serta perilaku guru sehari-hari berikut dalam proses mengajar (digunakan sebagai sebuah strategi dalam mengajar) sehingga akan berimbas pada proses belajar anak didik. HAM jadi penterjemahan aktual dari sistem akhak dikatakan bersifat menyeluruh dan menjadi metode sempurna yang meliputi seluruh gejala aktivitas biologis perorangan dan masyarakat, termasuk alam sekitarnya. Menurut Yaqin, hal tersebut termasuk dalam bagian dari sopan santun umum, sebab Islam memerintahkan bersopan santun kepada Allah, manusia, hewan dan makhluk-makhluk lain. $3^{6}$ Bahkan mengingat begitu urgen posisinya dalam Islam, Quran telah memuatnya dalam 1504 ayat, baik teoritis maupun praktis. Jumlah ini hampir 25\% dari keseluruhan. 37

HAM harus diperkenalkan pada seseorang haruslah sejak dari awal pendidikannya. Pengenalan tersebut meliputi pengenalan mengenai seluruh hierarki nilai-nilai sosial serta hak-hak kemanusiaan. Hal tersebut merupakan upaya agar anak mampu tumbuh dan berkembang sebagai orang yang secara sosial bertanggungjawab, mengetahui hak-hak orang tua, saudara, tetangga, masyarakat dan umat manusia sehingga secara

34 Fazlurrahman, Tema Pokok Al-Qur'an (Bandung : Pustaka, 1995)

35 Ismail dan Mukti, Pendidikan Islam, h. 124

36 Omar Muhammad Toumy Syaibany, Falsafat al-Tarbiyah al-Islamiyyah (Jakarta: Bulan Bintang,1979), terj. Hasan Langgulung, h. 325

37 Ibid., h. 313 
tidak langsung telah menjadikan norma universal sebagai sudut pandang kehidupan 38 .

Pola demikian, bagi Ibnu Miskawaih, merupakan merupakan fungsi dari pendidikan. Oleh karena itu, beliau menunjukkan bahwa memanusiakan manusia, sosialisasi individu manusia, serta penanaman rasa malu sebagai materi dasar dalam pendidikan39.

\section{a. Memanusiakan Manusia}

Manusia yang paling sempurna martabat kemanusiaannya adalah manusia yang paling mampu menunjukkan perilaku yang khas padanya dan yang paling teguh berpegang kepada syarat-syarat substansinya (daya pikir) yang paling membedakannya dengan mahkluk lain. ${ }^{40}$

Oleh karena tugas pendidikan adalah mendudukkan manusia dengan substansinya sebagai mahkluk yang ada. Hal ini ditandai dengan perilaku dan perbuatan yang khas bagi manusia yang tidak mungkin dilakukan mahkluk yang lain. Maka sudah menjadi kewajiban pendidikan sebagai ilmu yang termulia dari segala ilmu, memperhatikan perbaikan perilaku manusia sampai lahir darinya perbuatan-perbuatan serba sempurna sesuai dengan substansinya/hakekat kemanusiannya, serta mengangkat manusia dari tingkat terendah ke tingkat yang tertinggi.

\section{b. Sosialisasi Individu Manusia}

Pendidikan haruslah merupakan proses sosialisasi sehingga setiap individu merupakan bagian intergral dari masyarakatnya dalam melaksanakan kebajikan untuk kebahagiaan bersama. Selanjutnya Miskawaih menyatakan bahwa kebajikan itu sangat banyak dan beragam, maka tak mungkin seluruh kebajikan diwujudkan oleh perorangan, akan tetapi harus secara kolektif.

Kehidupan zuhud/uzlah ditolak dalam Islam, atau hidup menyepi dan menyendiri. Hal itu berlawanan dengan sifat asasi manusia. manusia

${ }^{8}$ Ali Ashraf, Horison Baru Pendidikan Islam (Jakarta: Pustaka Firdaus, 1996),

39 Ibn Miskawaih, Menuju Kesempurnaan Akhlak (Bandung : Mizan, 1997), terj. Helmi Hidayat,h. 135 .

40 Busyairi Madjidi, Konsep Kependidikan Para filosof Muslim, (Yogyakarta: alAmin Press, 1997), h. 39. 
dalam kesendiriannya tak akan ada Iffah (kesederhanaan), najdah (ketegaran), 'adālah (keadilan) dan kebajikan-kebajikan yang lain.

\section{c. Menanamkan rasa malu}

Rasa malu adalah rasa takut lahirnya sesuatu yang jelek dari dirinya, sehingga menurutnya timbulnya rasa malu pada diri anak adalah tanda awal perkembangan akalnya, karena hal itu menunjukkan bahwa anak sudah menginsyafi keburukannya berdasarkan pertimbangan akalnya. ${ }^{41}$

Ghazali memandang akhlak sebagai tingkah laku yang memiliki motivasi, tujuan dan obyek. Motivasi itu muncul dari dalam rangsangan dari luar dan berhubungan dengan kebutuhan jasmani dan kecenderungan alamiah manusia, seperti rasa lapar, cinta dan takut pada Allah. Menurutnya lagi, tingkah laku mempunyai tujuan keagamaan dan kemanusiaan, sedangkan obyeknya adalah semua aktivitas yang tidak berpisah dari rasa, perasaan dan kesadaran terhadap suasana sekitar. ${ }^{2}$

Permainan dalam olah raga memberikan rangsangan-rangsangan yang baik perkembangan kejiwaan anak untuk selalu siap menghadapi segala keadaan dan mampu bekerja sama dengan sesamanya. Dampak bagi kehidupan selanjutnya, anak siap untuk melakukan pembelaan hak hidup dan hak milik dengan ketrampilan yang dimilikinya.43

Dalam pandangan Ulwan, hal tersebut dipandang perlu diajarkan sehingga mampu terintegrasi dalam perilaku anak didik dalam menyikapi kehidupan. Untuk itu, ia merekomendasikan empat metode 44 :

1) Penanaman dasar-dasar kehidupan sosial seperti ukhuwwah, kasih sayang, altruisme (atsar 'alan-nafsi) pemaaf, berpegang teguh pada kebenaran yang semuanya didasarkan pada takwa kepada Allah SWT.

${ }^{41}$ Ibn Miskawaih, Menuju Kesempurnaan Akhlak, h. 75.

42 Hasan Langgulung, Azas-Azas Pendidikan Islam (Jakarta: Pustaka al-Husna, 1992), h. 274

43 Kamrani Buseri, Pendidikan Keluarga dalam Islam, cet I. (Yogyakarta : CV Bina Usaha, 1990), h. 44.

44 Abdullah Nasih Ulwan, Pendidikan Sosial Anak (Bandung: Remaja Rosda Karya: 1996), h.2 
2) Pemeliharaan hak-hak orang lain yaitu pergaulan hidup yang melukiskan keterlibatan anak dengan berbagai pihak: denganorang tua, guru, tetangga, teman, dan orang dewasa lainnya.

3) Berbagai kaidah hidup sosial seperti etiket makan minum, etiket bertamu, etiket berhubungan dengan sesama manusia etiket berbicara dan etiket melayat.

4) Kritik dan kontrol sosial yang penting bagi kehidupan.

Sedikit berbeda dengan Ulwan, Abrasyi menuturkannya secara lebih praktis, sebagai berikut:

1) pendidikan secara langsung, yaitu dengan cara mempergunakan petunjuk, tuntunan, nasehat, menyebutkan manfaat dan bahayabahayanya sesuatu baik melalui lagu, sajak, syair, musik atau lainnya; pada murid dijelaskan hal-hal yang bermanfaat dan yang tidak, menuntun kepada amal-amal baik, mendorong mereka berbudi pekerti yang tinggi dan menghindari hal tercela.

2) Secara tidak langsung, yaitu dengan jalan sugesti seperti membacakan sajak-sajak yang penuh hikmah, berita-berita berharga, ceritera dan lain-lain.

3) Mengambil manfaat dari kecenderungan dan pembawaan anak-anak. Sebagai contoh mereka memiliki kesenangan meniru ucapan, perbuatan, gerak-gerik orang yang berhubungan dengan mereka. Dari sini, guru dituntut untuk mampu menjadi figur percontohan bagi anak45.

\section{Penutup}

Manusia dalam penerimaan tatanan moral Islam melalui materi pendidikannya yang BTI tidak selalu sama dengan manusia lainnya. Ketidaksamaan ini disebabkan karena perbedaan karakter yang mendasari pada setiap individu. Karakter itu muncul sejak awal pertumbuhan mereka. Sejak usia anak-anak telah terlihat perbedaan di antara mereka, ada yang baik, kikir, pemberani, penakut, lembut, keras kepala, dengki dan sebaliknya. Implikasinya dalam menerima perbaikan juga sangat

45 M. Athiyah al Abrasyi, Dasar-Dasar Pokok Pendidikan Islam (Jakarta: Bulan Bintang, 1993), terj. BA Ghani \& Djohar Bahry, h. 106-109 
beragam. Perspektif BTI dalam Pendidikan Agama Islam itu telah mengharuskan pendidik menentukan strategi yang tepat guna membentuk pribadi muslim Indonesia bersusila menghargai kemajemukan.

Dalam tinjauan literature abad pertengahan Islam telah ada contoh bagaimana dimensi ibadah bisa berdampak kepada kesadaran akan kemajemukan dan kebhinekaan. Ibn Miskawaih telah mengenalkan ibadah haji sebagai usaha internalisasi nilai-nilai persaudaraan dan sosial.46 Karenanya, Penanaman perspektif Bhineka hendaknya dilaskanakan sejak anak usia dini sebagai bagian Pembentukan karakter seperti yang diusulkan oleh Setiani dan Nadjih.47 Perspektif itu menjadi payung karakter yang ditanamkan berdasar usulan keduanya, yaitu; Religius, Kedisiplinan, Toleransi, Kerja keras, Kreatif, Mandiri, Persahabatan/ komunikatif, Gemar membaca, Tanggung Jawab, Kepemimpinan, Sopan santun.

\section{Daftar Pustaka}

Ahmad, Zainal Abidin. Piagam Nabi Muhammad SAW Konstitusi Negara Tertulis Yang Pertama Di Dunia. Jakarta:Bulan Bintang, 1973.

Syaibany, Omar Muhammad al Toumy. Falsafah Pendidikan Islam. Jakarta: Bulan Bintang, 1979

Amiruddin, Pluralisme: Wacana, Praktek dan Penolakan. http//www.lkis.org./

Awan, Mahmud. The Faith Community And World Order In The Perspective Of Islam dalam Ismail raji al Faruqi (ed.), Trialogue of the Abrahamic Faiths. New Delhi: Genuine Publications Pvt. Ltd., 1989

Bawani, Imam. Tradisionalisme dalam Pendidikan Islam. Surabaya: al Ikhlas, 1993

Boisard, Marcel A. Humanisme Dalam Islam. Jakarta: Bulan Bintang, 1979

Fadjar, Abdullah. Peradaban dan Pendidikan Islam, Jakarta: Rajawali Pers, 1991

Feillard, Andree. NU Vis-a -Vis Negara; Pencarian Isi Bentuk Dan Makna. Yogyakarta: LkiS, 1999

Garcia, Ricardo L. Theaching In Pluralistic Society. New York: Harper \& Row Publishers, 1982

46 Ibn Miskawaih, Menuju Kesempurnaan, h.135.

47 Setiani \& Difla Nadjih, "Pembentukan Karakter Anak Usia Dini Melalui Pendidikan Agama Islam Di Tk ABA Kalibulus Rogobangsan Bimomartani Ngemplak Sleman," Jurnal Ulumuddin Volume 6, Nomor 2, Desember 2016, h. 125-136 
Hanurawan, Fattah. "Multicultural Perpective In Indonesian Social Sciences Studies And Student Prejudice Reduction” Jurnal Ilmu Pendidikan Edisi Desember 1998 volume 5 Nomor Suplemen.

Hasan, S. Hamid. pendekataan multikultural untuk penyempurnaan kurikulum nasional, http:// www.depdiknas.go.id/Jurnal/26/ hamid

Haroen, Hilman. "Epistimologi Idealistik Syekh Az-Zarnuji, Telaah Naskah Ta'lim Muta'allim," Jurnal Studi Islam Profetika 15 (2), 160-174.

Koentjaraningrat. Bunga Rampai Kebudayaan, Mentalitas dan Pembangunan. Jakarta: Gramedia, 1994

Kompas, Mutikulturalisme Di Tengah Kultur Monolitik Dan Uniformitas Global, Jum'at; 28 Desember 2001

Maarif, Ahmad Syafii. Peta Bumi Intelektualisme Islam di Indonesia. Bandung: Mizan, 1993

MS, Djohar Reformasi dan Masa Depan Pendidikan di Indonesia. Yogyakarta: IKIP Negeri Yogyakarta, 1999

Setiani \& Difla Nadjih. "Pembentukan Karakter Anak Usia Dini Melalui Pendidikan Agama Islam Di Tk ABA Kalibulus Rogobangsan Bimomartani Ngemplak Sleman," Jurnal Ulumuddin Volume 6, Nomor 2, Desember 2016, h. 125-136

Tilaar, HAR. Paradigma Baru Pendidikan Nasional. Jakarta: Rineka Cipta. 2000 